\title{
Dovitinib Lactate
}

National Cancer Institute

\section{Source}

National Cancer Institute. Dovitinib Lactate. NCI Thesaurus. Code C62435.

The orally bioavailable lactate salt of a benzimidazole-quinolinone compound with potential antineoplastic activity. Dovitinib strongly binds to fibroblast growth factor receptor 3 (FGFR3) and inhibits its phosphorylation, which may result in the inhibition of tumor cell proliferation and the induction of tumor cell death. In addition, this agent may inhibit other members of the RTK superfamily, including the vascular endothelial growth factor receptor; fibroblast growth factor receptor 1; platelet-derived growth factor receptor type 3; FMS-like tyrosine kinase 3; stem cell factor receptor (c-KIT); and colonystimulating factor receptor 1 ; this may result in an additional reduction in cellular proliferation and angiogenesis, and the induction of tumor cell apoptosis. The activation of FGFR3 is associated with cell proliferation and survival in certain cancer cell types. 